\title{
Problemy i rola ewangelików w katolickiej Polsce w refleksji religioznawczej Pawła Hulki-Laskowskiego
}

\author{
Rafał Marcin Leszczyński \\ Agnieszka Teresa Tys \\ Wydział Teologiczny \\ Chrześcijańska Akademia Teologiczna w Warszawie
}

\section{Abstract \\ The Problems and Role of Evangelicals in Catholic Poland in Pawel Hulka-Laskowski's Religious Studies}

The article reconstructs the views of Pawel Hulka-Laskowski, a prewar evangelical specialist in religious studies. In his opinion, the legally privileged position of the Roman Catholic Church in the Second Polish Republic resulted in the discrimination of religious minorities. In his works Hulka fought against the stereotype of the Polish Catholic, emphasising the contribution of evangelicals to Polish culture. He saw the full bloom of Poland in the 16th century as being strongly connected to the development of reformation in the country, as Evangelicalism is a religion stimulating cultural progress. Therefore, if certain Protestant ideals were applied in contemporary Polish Catholicism, it, together with the Polish culture, could be raised to a higher level.

Key words: Pawel Hulka-Laskowski, reformed evangelicalism, liberal theology, religious studies, Polish culture, Polish Catholicism

Słowa kluczowe: Paweł Hulka-Laskowski, ewangelicyzm reformowany, teologia liberalna, religioznawstwo, kultura polska, polski katolicyzm

\section{Wstęp}

Wśród wybitnych Polaków wyznania ewangelicko-reformowanego, takich jak Mikołaj Rej, Jan Łaski, Bronisław Trentowski, Stefan Żeromski, należy wymienić także Pawła Hulkę-Laskowskiego (1881-1946), syna robotników żyrardowskich o czeskobraterskich korzeniach, który dzięki swojemu wielkiemu talentowi i pracowitości stał się w okresie międzywojennym jednym z najbardziej znanych ewangelickich intelektualistów. Obecnie postrzegany jest przede wszystkim jako pierwszy tłumacz Przygód dobrego wojaka Szwejka na język polski, warto jednak pamiętać, że działalność 
translatorska stanowiła tylko jeden z obszarów jego twórczości, Hulka-Laskowski był bowiem przede wszystkim religioznawcą i filozofem. O wysokich kompetencjach Hulki w zakresie owych dyscyplin świadczy choćby jego wykształcenie, które zdobył na uniwersytecie w Heidelbergu (1903-1907), gdzie zaproponowano mu nawet napisanie doktoratu i habilitacji. Hulka postanowił jednak powrócić do Żyrardowa (1908), aby pomagać tamtejszym robotnikom w walce o ich prawa oraz założyć dla nich uniwersytet robotniczy ${ }^{1}$.

Po przyjeździe z Heidelbergu Hulka kontynuował działalność naukową. Istotną rolę w jego biografii odegrał w tym czasie twórca „Myśli Niepodległej” - Andrzej Niemojewski. W jednym ze swoich listów Hulka-Laskowski podkreślał, że wiele się od niego nauczył w dziedzinie publicystyki². Współpracę z Niemojewskim rozpoczął od pisania recenzji tekstów czeskich wolnomyślicieli, jednak wkrótce zaczęto przyjmować również artykuły Hulki o tematyce religioznawczej i filozoficznej ${ }^{3}$. Niebawem jego nazwisko stało się znane w kręgach polskich inteligentów. Można je odnaleźć na łamach pism wolnomyślicielskich, literackich oraz czasopism wydawanych przez Kościoły mniejszościowe w Polsce. Hulka opublikował także cały szereg prac zwartych o charakterze filozoficzno-religioznawczym, z których ważniejsze pojawiają się w bibliografii do niniejszego artykułu. Jest on również autorem pierwszej powieści poświęconej sytuacji polskich ewangelików w II Rzeczypospolitej, zatytułowanej Porucznik Regier ${ }^{4}$.

\section{Problemy prawne ewangelików i innych mniejszości}

Jednym z zagadnień stale podnoszonych przez Hulkę była sytuacja prawna wyznań mniejszościowych, które - w jego ocenie - nie miały równego statusu z Kościołem rzymskokatolickim. W przekonaniu Laskowskiego postępowe treści konstytucji marcowej nie odzwierciedliły się na płaszczyźnie praktycznej, czyli w życiu polskiego społeczeństwa. Chodzi oczywiście o artykuły wyznaniowe konstytucji, a konkretnie art. 111 i 112 dotyczące wolności sumienia i wyznania. Miały one zapewniać wszystkim obywatelom Polski równość wobec prawa bez względu na wyznanie oraz prawo wolnego wyznawania - zarówno publicznie, jak i prywatnie - swej wiary. Hulka uważał jednak, że zapisy te nie są de facto przestrzegane ${ }^{5}$. Według niego

\footnotetext{
1 Por. R. Leszczyński (senior), Trudne życie [w:] Paweł Hulka-Laskowski (1881-1946). Szkice do portretu, R. Leszczyński (red.), Żyrardów 1995, s. 5-11; idem, Paweł Hulka-Laskowski wobec kultury czeskiej [w:] Paweł Hulka-Laskowski (1881-1946)...., s. 44-45; R.M. Leszczyński (junior), Całożyciowe uczenie się Pawła Hulki-Laskowskiego (1881-1946) - stymulatory i bariery [w:] Biografia i badanie biografii, t. 4: Biografie i uczenie się, E. Dubas, J. Stelmaszczyk (red.), Łódź 2015, s. 71-74.

2 Por. P. Hulka-Laskowski, list do Jana Sławiczka z 14.01.1942, s. 1. List znajduje się w archiwum śp. Jana Brody ze Skoczowa i został udostępniony R.M. Leszczyńskiemu (juniorowi) przez jego córkę, p. Martę Mattes. Inne listy Hulki przytoczone w niniejszym opracowaniu również pochodzą z tego archiwum.

3 Por. ibidem.

4 Por. R.M. Leszczyński (junior), op.cit., s. 72-73; R. Leszczyński (senior), Trudne..., s. 6-7.

5 Por. P. Hulka-Laskowski, Porucznik Regier, Warszawa 1927, s. 248.
} 
[...] gdyby nasza konstytucja była o połowę mniej liberalną, ale wcieloną w życie, to byłoby nam wszystkim lepiej, bo dzisiaj jest na papierze, a nad życiem panują potęgi zgoła nieliberalne i ciemne ${ }^{6}$.

Z powyższego wynika, że Hulka oceniał konstytucję marcową w gruncie rzeczy pozytywnie. Nie krytykował nawet bezpośrednio art. 114, gwarantującego Kościołowi rzymskokatolickiemu uprzywilejowaną pozycję wśród innych wyznań. Koncentrował się natomiast na problemie - w swoim przeświadczeniu - znacznie ważniejszym. Według niego w żadnej ze współczesnych konstytucji nie ma tylu artykułów dotyczących wolności sumienia i wyznania, jednak , ,...] artykuły mówiące na przykład o uznaniu nowego lub prawnie dotąd nieuznanego wyznania oraz samodzielności i równouprawnieniu wszystkich związków religijnych pozostały martwą literą [...]", ponieważ w praktyce bardzo wielu denominacjom odmawia się legalizacji, a równouprawnienie wyznań jest fikcją ${ }^{7}$.

Paweł Hulka-Laskowski twierdził, że naruszanie zasady równouprawnienia wyznań widać wyraźnie na gruncie prawa małżeńskiego. Hulka dotykał tej drażliwej kwestii wielokrotnie w swojej publicystyce ${ }^{8}$, a także w Poruczniku Regierze, gdzie opisał autentyczny przypadek małżeństwa ewangeliczki z katolikiem, które uznano za nieważne, gdyż zostało zawarte przed duchownym protestanckim ${ }^{9}$.

Warto w tym miejscu wyjaśnić, skąd wynikały wspomniane problemy. Otóż Polska po odzyskaniu niepodległości odziedziczyła różne kodeksy prawa obowiązujące na ziemiach okupowanych przez zaborców. Jednym z najważniejszych zadań odrodzonego państwa stało się zatem ujednolicenie prawa na terenie II Rzeczypospolitej przez powołaną do tego celu Komisję Kodyfikacyjną. Prace nad kodyfikacją prawa małżeńskiego toczyły się w Sekcji Prawa Cywilnego, a ich ukoronowaniem był projekt Karola Lutostańskiego, popierany gorąco przez Hulkę. Żyrardowianin wiązał z nim nadzieję na zrównanie prawne małżeństw katolickich $\mathrm{z}$ niekatolickimi ${ }^{10}$. Lutostański przekształcił model wyznaniowy prawa małżeńskiego w model świecki, znosząc tym samym jurysdykcję duchowieństwa i dopuszczając rozwody. Z powodu fali protestów środowisk rzymskokatolickich ${ }^{11}$ projekt ów został jednak odrzucony w Sejmie i przez cały okres II Rzeczypospolitej w zakresie prawa małżeńskiego obowiązywały regulacje prawne państw zaborczych. Przykładowo, na terenie byłego Królestwa Polskiego obowiązywało prawo małżeńskie z roku 1836, które miało charakter wyznaniowy z odrębnością dla czterech wyznań chrześcijańskich: rzymskokatolickiego, prawosławnego, ewangelicko-augsburskiego i ewangelicko-reformowanego, zaś

${ }^{6}$ Ibidem, s. 246.

7 Idem, Polska wspótczesna i ludzie tratwy, „Jednota” 1932, nr 12, s. 189.

${ }^{8}$ Por. P. Hulka-Laskowski, Do szeregów!, „Zwiastun Ewangeliczny” 1928, nr 2, s. 13; idem, Demokracja i hierokracja, „Zwiastun Ewangeliczny” 1928, nr 4, s. 28-29; idem, Co zostało skazane wyrokiem wileńskim, „Jednota” 1929, nr 1, s. 12-15.

${ }^{9}$ Por. idem, Porucznik..., s. 284-287, 289-290, 319-329.

${ }_{10}$ Por. idem, Ludzie..., s. 191.

${ }^{11}$ Por. W. Abraham, Zagadnienie kodyfikacji prawa malzeńskiego, Lublin 1929; S. Biskupski, Rozwody w projekcie prawa małżeńskiego Komisji Kodyf. Rz.P., „Ateneum Kapłańskie” 1931, t. 28, s. 275 282; W sprawie projektu ustawy o malżeństwie. Orędzie Episkopatu Polski, „Miesięcznik Kościelny Archidiecezji Gnieźnieńskiej i Poznańskiej” 1931, nr 11, s. 206-208. 
jurysdykcję sądową pełniło duchowieństwo ${ }^{12}$. Należy podkreślić, że w czasach zaboru rosyjskiego wyznaniem uprzywilejowanym było prawosławie, dlatego też sprawy małżeństw mieszanych zostały uregulowane na jego korzyść. W II Rzeczypospolitej nastąpiła inwersja na rzecz Kościoła rzymskokatolickiego, a podstawą prawną stało się nieprzewidujące rozwodów katolickie prawo kanoniczne. W świetle tych zasad małżeństwa protestanckie były uważane za konkubinat. Jak podkreśla Laskowski, było to prawo okrutne i bezwzględne. Katolik mógł łatwo doprowadzić do unieważnienia małżeństwa, jeśli zawierał je w Kościele ewangelickim, co oczywiście miało również swoje reperkusje majątkowe ${ }^{13}$.

\section{Krzywdzące stereotypy}

Problemy prawne mniejszości wyznaniowych w II Rzeczypospolitej były - według Hulki - skutkiem fenomenu znacznie bardziej niepokojącego od niedoskonałej legislacji. Zjawisko to polega na utożsamieniu wyznania z narodowością, a konkretnie na zrównaniu polskości z rzymskim katolicyzmem ${ }^{14}$. Zdaniem ewangelika z Żyrardowa hasło „Polak-katolik”

[...] jest wybitnie polemiczne, bojowe, zaczepne, nieprzyjazne, często wrogie. [...] W haśle, że Polak to katolik, nie było nigdy ani śladu miłości, nawet dla polskości i katolicyzmu. Była w nim zawsze ta nienawiść aktywna, która szuka przedmiotu nienawiści i znajduje go za wszelką cenę ${ }^{15}$.

Dzieje się tak, ponieważ ze stereotypu „Polak-katolik” wynika - w opinii Hulki-Laskowskiego - tendencja do wykluczania z narodu polskiego wszystkich niekatolików i przypisywania im obcej narodowości - w przypadku ewangelików, narodowości niemieckiej ${ }^{16}$. Od tego jest już tylko krok do stwierdzenia, że ewangelicy jako Niemcy nie mogą mieć w państwie polskim takich samych praw jak Polacy-katolicy.

W dogmacie „Polak-katolik” tkwi więc - w przekonaniu Hulki - ogromna siła hamująca pęd ku polskości tych wszystkich osób, które nie należą do Kościoła rzymskokatolickiego ${ }^{17}$. Jeśli zatem ludzie ci pomimo wszystko postanawiają trwać przy Polsce, to odbywa się to kosztem wielkiego wysiłku z ich strony. Hulka twierdził, że

[...] wiele energii i siły pochłania w Polsce szukanie drogi do ojczyzny każdej jednostce obcego pochodzenia i niekatolickiego wyznania, gdy w zaraniu życia zamiast szeroko rozwartych

${ }_{12}$ Por. K. Lutostański, Prawo cywilne obowiazujace w bylym Królestwie Polskim, t. 1, Warszawa 1931, s. 58; M. Pietrzak, Prawo wyznaniowe, Warszawa 2003, s. 125.

${ }_{13}$ Por. P. Hulka-Laskowski, Porucznik..., s. 287.

${ }^{14}$ Por. F. Rosica [P. Hulka-Laskowski], Polsko twa zguba w Rzymie, Chicago b. r., s. 7; P. Hulka-Laskowski, Polska wierzaca, Warszawa 1929, s. 20-22, 85-86; idem, Pro Russia - contra Polonia, „Jednota” 1932, nr 11, s. 157.

${ }_{15}$ P. Hulka-Laskowski, Przedmowa [w:] idem, Pięć wieków herezji. Wypisy z literatury polskiej, Warszawa 1960, s. 43.

${ }^{16}$ Por. ibidem, s. 35, 43. Zob. też idem, Dokoła listu p. Simplexa. Przyznanie i wyznanie, „Zwiastun Ewangeliczny" 1928, nr 3, s. 20.

17 Por. P. Hulka-Laskowski, Przedmowa..., s. 30. 
ramion braci i przyjaciół widzi wyniosły gest władców, stawiających miłości młodego serca twarde warunki inkwizytorskie ${ }^{18}$.

Pisząc te słowa, Hulka-Laskowski bynajmniej nie teoretyzował, gdyż jako potomek braci czeskich i ewangelik reformowany znał ów problem z autopsji, bowiem już za młodu doświadczał ostracyzmu ze strony katolickich rówieśników. W „Wiadomościach Literackich” wyznał:

Zacząłem cierpieć bardzo wcześnie za swój kalwinizm [...]. Grube kpiny z herezji, niskie parodie kazań ewangelickich, wyzwiska, czasem kuksaniec nie pozwalały ani na chwilę zapomnieć, że jestem kalwinem ${ }^{19}$.

Laskowski wspominał, że w Żyrardowie pod adresem dzieci ewangelickich recytowano taki oto wierszyk: „Niemcze, szwabie, kartoflarzu, gonisz dziwki po cmentarzu, Pana Boga nie znasz, kopytem się żegnasz". Do wiersza tego dodawano komentarz: „Jesteś Luter i szwab, i bawić się z tobą nie będziemy”. Na domiar złego stereotyp ów nie dotyczył tylko młodszych dzieci, gdyż kontynuowany był w szkole i dorosłym życiu. Według Hulki ,[...] w szkole były już bardzo wyraźne stronnictwa: tu prawowierni, tu heretycy, tu Polacy, tam »Szwaby«. I tak już zostało przez cały czas szkoły, w fabryce, w domach fabrycznych" ${ }^{20}$.

Jak wiadomo, Hulka wyrwał się z robotniczego środowiska, w jakim się wychował, stając się znanym intelektualistą. Atoli okazało się, że stereotyp „Polak-katolik” funkcjonuje nie tylko w środowisku robotniczym, lecz także wśród sporej części inteligencji. Pisał Hulka:

Potem czytało się czarno na białym, że Polak to katolik. To była sugestia potężna, sugestia drukowanego słowa. Wszystko składało się na to, [...] że do Polski jako ojczyzny prowadzi droga tylko przez Kościół [rzymskokatolicki] ${ }^{21}$.

Laskowski uważał, że jego odmienność wyznaniowa w wielu wypadkach utrudniała mu pracę naukową i publicystyczną, ponieważ w różnych periodykach bywał wielokrotnie bezpardonowo atakowany ze względu na swoje ewangelickie poglą$\mathrm{dy}^{22}$. Zresztą dla adwersarzy Hulki sam fakt, że jest „kalwinem”, był wystarczającym powodem do odrzucania jego przekonań, bez głębszej analizy krytykowanych tez ${ }^{23}$. Zdarzało się również, iż odmawiano mu publikowania prac w związku z ich rzekomo nieprawowierną, ewangelicką treścią 24 . Hulka uważał, że gdyby nie jego wyznanie, to mógłby być ,[...] współpracownikiem bogatych i świetnie płacących pism,

18 Ibidem, s. 18. Zob. też na podobny temat idem, Droga do ojczyzny $i$ zapory, „Zwiastun Ewangeliczny" 1938, nr 11, s. 122.

19 Idem, Spowiedź kalwina, ,Wiadomości Literackie” 1933, nr 54, s. 1.

${ }^{20}$ Idem, Przedmowa..., s. 20.

21 Ibidem, s. 21. Zob. też idem, Polsko twa zguba..., s. 37.

22 Por. idem, Krytyka grubiaństwem, „Jednota” 1926, nr 12, s. 183-184.

${ }^{23}$ Por. idem, Moim korespondentom, ,Jednota” 1933, nr 12, s. 174-175.

24 Por. idem, list do Jana Wantuły z 28.12.1929, s. 1. 
zajmować wybitne stanowiska społeczne, być może dotarłbym jako członek jakiej rady nadzorczej do dobrobytu i radości życia"25.

Podobne doświadczenia były udziałem również innych ewangelików. Do Laskowskiego, jako znanego pisarza ewangelickiego, dochodziły nieustannie sygnały o dyskryminacji jego współwyznawców i prośby o nagłaśnianie ich problemów przez publikacje, co też Hulka starał się czynić ${ }^{26}$. Sytuację ową religioznawca z Żyrardowa oceniał następująco: „Widziało się obok siebie ludzi, którzy wrośli w kulturę polską bez jakichkolwiek zastrzeżeń, ale wciąż byli wyłączani ze społeczności narodowej za to, że wyznawali wiarę ewangelicką $[\ldots]^{\prime 27}$.

\section{Apologia ewangelicyzmu}

Doznanie odrzucenia sprawiło, że jednym z ważniejszych wątków w twórczości religioznawczej Pawła Hulki-Laskowskiego stała się walka ze stereotypem Polaka-katolika i Niemca-ewangelika. Ważnym argumentem Hulki wymierzonym w takie myślenie było spostrzeżenie, że jest ono niebezpieczne nie tylko dlatego, iż narusza prawa ewangelików, ale również z tej przyczyny, że pozbawia naród polski wartościowych obywateli wyznania ewangelickiego, zubażając w ten sposób jego kulturę i historię ${ }^{28}$. Warunkiem przetrwania narodu polskiego w jego niełatwej sytuacji geopolitycznej jest ekspansja kulturowa, czyli pozyskiwanie dla kultury polskiej osób obcego pochodzenia i różnych światopoglądów religijnych. Tylko naród prowadzący taką ekspansję liczy się na arenie międzynarodowej ${ }^{29}$. Sprowadzając natomiast polskość do rzymskiego katolicyzmu, zamyka się drogę do kultury polskiej wszystkim niekatolikom, tym samym osłabiając naród polski ${ }^{30}$, bo żaden naród, nawet najsilniejszy, nie może pozwolić sobie na odrzucanie tysięcy ludzi garnących się do niego ${ }^{31}$. Ponadto konsekwentne zrealizowanie hasła „Polak-katolik” oznaczałoby, „[...] że Polacy wyznania prawosławnego, ewangelickiego, i każdego innego [...], musieliby automatycznie znaleźć się poza Polską i przyłączyć do Niemców, Rosjan, Turków czy któregokolwiek narodu"32.

Zdaniem Hulki, wymiatając protestantyzm z Polski - co postulował Roman Dmowski i jemu podobni ${ }^{33}$ - należałoby także pozbyć się ważnej części polskiego dziedzictwa kulturowego ${ }^{34}$. Uzasadniając ową tezę, Hulka wskazywał na postacie wybitnych Polaków wyznania ewangelickiego, którzy przyczynili się do rozwoju polskiej kultury. Wymieniał zatem wśród nich Mikołaja Reja, Stanisława Murzynowskiego, Andrzeja Trzecieskiego, Jakuba Lubelczyka, Jana Łaskiego, Daniela

\footnotetext{
25 Idem, Spowiedź..., s. 1.

26 Por. idem, list do Jana Wantuły z 28.12.1929, s. 1.

27 Idem, Przedmowa..., s. 21.

28 Por. idem, Polska..., s. 4-5.

29 Por. ibidem, s. 10-13.

30 Por. ibidem, s. 20-21.

31 Por. idem, Przedmowa..., s. 35, 50-51.

32 Idem, Do szeregów!..., s. 13.

33 Por. idem, Dokoła listu..., s. 20.

34 Por. idem, Przedmowa..., s. 32, 34.
} 
Naborowskiego, Samuela Bogumiła Lindego, Bronisława Trentowskiego, Stefana Żeromskiego i innych. Nie zapomniał również wspomnieć o wybitnych ewangelickich patriotach - generale Henryku Dąbrowskim, generale Stanisławie Fiszerze, Józefie Hanke-Bosaku i Szymonie Konarskim ${ }^{35}$. Żyrardowianin przypominał także, iż rozwój kultury polskiej w XVI wieku był ściśle powiązany z pojawieniem się reformacji w naszym kraju. Dzięki reformacji rozkwitła w tym czasie oświata i literatura $\mathrm{w}$ języku polskim, przebudził się duch narodowy, podniósł poziom moralny społeczeństwa, a także świadomość obywatelska ${ }^{36}$. Nie można więc usunąć wpływów ewangelickich z kultury polskiej, nie niszcząc przy okazji jej istotnej części. Tak nieomal stało się w czasach saskich, czyli w epoce najgłębszego upadku polskiej kultury, gdy wypchnięto ewangelików z przestrzeni publicznej, a światłych braci polskich od wielu lat nie było już w naszym kraju ${ }^{37}$. Według Laskowskiego

[...] czy chcemy, czy nie chcemy, musimy ustosunkować się do faktu, że właśnie Reformacja dała narodowi polskiemu wiek złoty jego kultury i że ojcem piśmiennictwa polskiego jest protestant [Rej]. Rozkwit państwa i narodu polskiego łączy się tak nierozerwalnie z Reformacją, że dzisiaj widzimy dość wyraźnie, iż upadek państwa polskiego zaczął się z upadkiem Reformacji i spotężnieniem reakcji katolickiej. Podczas gdy w sprotestantyzowanej Polsce odzywały się mądre głosy Modrzewskich, zamyślających się głęboko nad koniecznością naprawy Rzeczypospolitej, gdy śpiewakiem jej był wielki Kochanowski, w Polsce zawojowanej na nowo przez katolicyzm największym myślicielem był twórca obskurnych Nowych Aten, ksiądz Chmielowski, a jej najwybitniejszym poetą był ksiądz Baka $^{38}$.

Hulka-Laskowski sądził, że kontrreformacji nie udało się jednak wyplenić całkowicie ideałów ewangelickich z polskiego społeczeństwa. Ujawniają się one choćby w twórczości wybitnych polskich autorów, którzy niekoniecznie zresztą byli formalnie ewangelikami, jednak ich sposób myślenia przesycony był - zdaniem Hulki koncepcjami reformacyjnymi, na przykład krytycznym stosunkiem do instytucji papiestwa, klerykalizmu itp. Zgodnie z duchem reformacji pisarze ci stawiali wolność sumienia i badania oraz sprawę narodową ponad interesem Rzymu. Hulka wymienia w tym kontekście Mickiewicza, Słowackiego, Towiańskiego, Cieszkowskiego, Staszica, Goszczyńskiego, Świętochowskiego, Niemojewskiego, Lelewela, Górskiego, Konopnicką, Witkiewicza itp., twierdząc, że ich dzieła są kamieniem węgielnym polsko-ewangelickiej ideologiii ${ }^{39}$.

${ }^{35}$ Por. ibidem, s. 21-22, 25-26, 32, 35, 49-50; idem, Polsko twa zguba..., s. 55-56; idem, Wileński Kościót Ewangelicko-Reformowany (b. Jednota litewska) na tle Reformacji i kultury polskiej, Wilno 1936, s. 6, 8, 18-21, 26, 28-29; idem, Rola i zadania inteligencji ewangelickiej w naszym życiu religijno-kościelnym. Referat odczytany na VI Zjeździe Polaków Ewangelików dnia l listopada 1929 r. w Krakowie, Warszawa 1930, s. 10, 13; idem, Mikołaj Rej, „Jednota” 1934, nr 5, s. 71-73; idem, Świadomość i godność, „Zwiastun Ewangeliczny” 1928, nr 45, s. 431; idem, Bronisław Ferdynand Trentowski, „Jednota” 1926, nr 6, s. 93-95; idem, Stare ceterum senso, „Zwiastun Ewangeliczny” 1928, nr 29, s. 221-222.

${ }^{36}$ Por. idem, list do Jana Wantuły z 24.12.1928, s. 1; idem, Wileński Kościół..., s. 6-8, 15-19, 20, 22-23, 25-27; idem, Polska..., s. 3, 63-64.

${ }^{37}$ Por. idem, Polska.., s. 3, 22-23; idem, Polsko twa zguba.., s. 20-22; idem, Wileński Kościót..., s. 8.

${ }^{38}$ Idem, Polska..., s. 16.

${ }_{39}$ Por. idem, Rola i zadania..., s. 10, 13; idem, Przedmowa..., s. 21-22, 25, 32, 35, 46, 50; idem, Polska.., s. 46-47, 81-84; idem, Polsko twa zguba..., s. 23, 55-56; idem, Wileński Kościót.., s. 21-22. 
Jak więc widać - w przekonaniu Hulki - po stronie idei ewangelickich stoją wielcy Polacy ze Słowackim i Mickiewiczem na czele, w związku z tym usuwanie ewangelicyzmu poza nawias polskości musi prowadzić do wykluczenia ze wspólnoty narodowej również owych wybitnych postaci ${ }^{40}$.

Hulka-Laskowski twierdził, że ewangelicyzm mógł podnieść w XVI wieku kulturę polską na wyższy poziom, ponieważ jest religią stymulującą rozwój kultury. Łącząc ze sobą ewangelicką teologię liberalną i filozofię Fryderyka Nietzschego, Hulka głosił, że religia staje się czynnikiem rozwoju kultury, gdy zamiast koncentrować się na zbawieniu w zaświatach, inspiruje swoich wyznawców do walki o świat doczesny, transformując go w miejsce, w którym ludzie mogą prowadzić godne i wzniosłe życie ${ }^{41}$. Królestwo Boże nie jest więc rzeczywistością eschatologiczną, gdyż aktualizuje się ono w świecie doczesnym przez kulturotwórcze czyny poszczególnych ludzi. W taki właśnie sposób o Królestwie Bożym myślał Zaratustra i jego wyznawcy, dlatego też zaratustrianizm jest religią prokulturotwórczą ${ }^{42}$. Potencjał kulturotwórczy chrześcijaństwa jest natomiast mocno ograniczony, ponieważ chrystianizm ma na ogół charakter soteriocentryczny i eschatocentryczny ${ }^{43}$. Wyjątkiem jest tutaj protestantyzm, który dokonuje afirmacji życia w świecie, starając się być wierny ziemi, a nie zaświatom. Ewangelicy, podobnie jak zaratustrianie, wierzą, że przez ich czyny już tu na ziemi tworzy się Boże Królestwo i zaczyna się żyć życiem wiekuistym ${ }^{44}$. $\mathrm{Z}$ tego powodu ewangelicyzm podniósł kulturę narodów, które go przyjęły, na wyższy poziom. Wyższość kulturowa ludów protestanckich sprawia, iż przodują one na świecie pod względem politycznym, gospodarczym, umysłowym i moralnym ${ }^{45}$. W opinii Hulki, jeśli w krajach katolickich dokonał się jakiś postęp, to stało się tak za sprawą oddziaływania na nie ewangelicyzmu, a zatem większego lub mniejszego ich sprotestantyzowania ${ }^{46}$. Pisał Hulka:

Statystyka światowa wykazuje przewagę oświaty i twórczej inicjatywy po stronie protestanckiej, ale faktem jest, że tam, gdzie katolicyzm sąsiaduje z ewangelicyzmem, jego poziom jest

40 Por. idem, Przedmowa..., s. 32, 34.

${ }^{41}$ Por. idem, list do Pawła Kotasa z 16.12.1943, s. 4, 7; idem, Porucznik..., s. 218; idem, Droga do kultury. Szkic społeczno-religijny, Łódź 1922, s. 10.

${ }^{42}$ Por. idem, Zaratustra - twórca religii Iranu, Warszawa 1912, s. 3-9, 53; idem, Persja, Indie, Chiny [w:] Noty do wykładów pt. „Dzieje cywilizacji” wygłoszonych w stowarzyszeniu „Samoksztatcenie”, Żyrardów 1917-1919, s. 8, 21 (zeszyt z rękopiśmiennymi notatkami Hulki przechowywany jest w dziale Zbiorów Specjalnych Biblioteki Uniwersyteckiej w Łodzi, gdzie oznaczono go sygnaturą Rps 5037/3). Moc kulturotwórczą ma także - według Hulki - nauka Mojżesza, Buddy i Mahometa (idem, Polska..., s. 13), jednak już hinduizm jest jej pozbawiony, ponieważ ,[...] myśl indyjska błąka się po bezdrożach tęsknot zaświatowych" (idem, Persja, Indie, Chiny..., s. 25).

${ }_{43}$ Por. idem, Człowiek, „Wiadomości Literackie” 1935, nr 27, s. 1; idem, Droga..., s. 9; idem, Porucznik..., s. 204-205; idem, Mój Żyrardów. Z dziejów polskiego miasta i z życia pisarza, Warszawa 1958, s. 70-71, 155-156, 295-296, 344-345.

${ }^{44}$ Por. idem, Polska..., s. 15-16. Zob. też K. Howorko [P. Hulka-Laskowski], Wyznanie a uspołecznienie, ,Pielgrzym Polski” 1946, nr 9, s. 4-5.

${ }^{45}$ Por. idem, Polska..., s. 13-14; idem, Przedmowa..., s. 30; idem, Polsko twa zguba..., s. 21-22, 5152; idem, Porucznik..., s. 262-263; idem, Rekolekcje przedwyborcze, „Jednota” 1927, nr 11, s. 161-163.

${ }^{46}$ Por. idem, Polska..., s. 16. 
znacznie wyższy niż w krajach wyłącznie katolickich bez mniejszości ewangelickiej. Dość porównać na przykład Bawarię i Hiszpanię, aby dostrzec te różnice, o których tu mówimy ${ }^{47}$.

Również w szesnastowiecznej, sprotestantyzowanej Polsce jakość katolicyzmu poprawiła się, co pozytywnie wpłynęło na jej kulturę ${ }^{48}$.

W swojej twórczości Hulka starał się udowodnić, że ewangelicyzm ma dla Polski nie tylko znaczenie historyczne, ale nadal może być dla naszego kraju ważnym czynnikiem kulturotwórczym. Żyrardowianin zdawał sobie oczywiście sprawę z tego, że Polska jest krajem rzymskokatolickim i że nie ma już powrotu do sytuacji z czasów renesansu, gdy istniała nadzieja na zwycięstwo reformacji w Rzeczypospolitej. Ponadto Laskowski wielokrotnie podkreślał, że nie zamierza nawracać katolików na ewangelicyzm. W jednym ze swoich listów wyznał:

Nie myślałem nigdy o nawracaniu katolików. Kocham ich takimi, jakimi są, bo są to bracia nasi, ale wiem, że samo istnienie szlachetnego, mądrego i dzielnego ewangelicyzmu musi wpłynąć na gatunek katolicyzmu i podnieść go, a tym samym podnieść poziom kultury narodowej ${ }^{49}$.

Okazuje się zatem, że Hulka miał nadzieję, iż katolicyzm polski, przez sam fakt otworzenia się na ewangelicyzm, ulegnie sprotestantyzowaniu, podobnie jak stało się to w krajach zachodnich, i w ten sposób podniesie polską kulturę na wyższy poziom.

\section{Zakończenie}

Ograniczona objętość niniejszego artykułu nie pozwala poruszyć wszystkich aspektów twórczości religioznawczej Hulki, z tego powodu skupiono się w nim na przedstawieniu jej wymiaru apologetycznego, choć i na tym polu konieczne było dokonanie sporych skrótów. Artykuł niniejszy należy zatem potraktować jako zarys zagadnienia i przyczynek do dalszych badań nad dorobkiem religioznawczym Hulki.

Z powyższych wywodów płynie konkluzja, że twórczość Pawła Hulki-Laskowskiego dotykała punktów zapalnych w relacjach katolicko-ewangelickich, będąc reakcją na problemy mniejszości wyznaniowych zamieszkujących katolicką Polskę. Apologetyczny charakter owej twórczości sprawił, iż pojawiają się w wypowiedziach Hulki pewne przejaskrawienia, jak choćby teza o niemocy kulturotwórczej katolicyzmu, jeśli bowiem nawet przyjmiemy twierdzenie, że społeczeństwa ewangelickie są bardziej rozwinięte od katolickich, to przecież nie można jednak pomijać faktu, iż katolicyzm także wniósł swój pozytywny wkład do rozwoju kultury europejskiej i ogólnoświatowej. W tym miejscu warto podkreślić, że ewangelik z Żyrardowa był świadomy tego, iż część wyrażonych przez niego opinii ma charakter emotywny, będąc reakcją na przykrości doznane ze strony rzymskich katolików. W Pięciu wiekach herezji Hulka-Laskowski ze skruchą wyznał: „Przyznaję się, że na złe uczucia reagowałem często uczuciami podobnymi, co jest zresztą rzeczą ludzką

\footnotetext{
${ }^{47}$ Idem, Wileński Kościół..., s. 35.

${ }^{48}$ Por. ibidem, s. 23.

49 Idem, list do Jana Wantuły z 24.12.1928, s. 1.
} 
- arcyludzką" ${ }^{50}$. Na przyszłe relacje katolicko-ewangelickie w Polsce patrzył wszakże z nadzieją, gdyż dostrzegał pojawienie się wśród rzymskich katolików osób otwartych na dialog. We wspomnianych Pięciu wiekach... napisał zatem, co następuje:

W czasach ostatnich zacząłem się spotykać z nowym typem katolika, z takim, co nie potępia a priori, nie wyrzuca z narodu, nie wyklucza dobrej wiary u innowiercy, a nawet uważnie wsłuchuje się w jego słowa i nie waha się powiedzieć, że te słowa bywają godne zastanowienia. Tu kończy się walka, tu rozwiewają się uczucia złe, nastaje pokój i braterstwo ${ }^{51}$.

Pomimo uprawianej przez Hulkę apologetyki ewangelicyzmu właśnie o to braterstwo chodziło mu najbardziej.

Czytając i oceniając teksty Pawła Hulki-Laskowskiego, pamiętać trzeba, że konfrontacyjny ton Hulkowych artykułów i prac zwartych oraz zabiegi retoryczne występujące w jego pismach nie odbiegały zasadniczo od stylu polemik prowadzonych w okresie międzywojennym, wypełnionych sporą dozą emocji i ostrych sformułowań. Pomimo owych zastrzeżeń wobec dorobku żyrardowskiego pisarza należy przyznać, iż jego twórczość oparta była na faktach, rozległej wiedzy i solidnym warsztacie naukowym, który Laskowski wyniósł ze studiów religioznawczych i filozoficznych w Heidelbergu. Z tego powodu posiada ona, jako obiekt badań, sporą wartość.

\section{Bibliografia}

Abraham W., Zagadnienie kodyfikacji prawa matzeńskiego, Lublin 1929.

Biskupski S., Rozwody w projekcie prawa matżeńskiego Komisji Kodyf. Rz.P., „Ateneum Kapłańskie" 1931, t. 28 , s. 275-282.

Howorko K. [Hulka-Laskowski P.], Wyznanie a uspołecznienie, „Pielgrzym Polski” 1946, nr 9, s. 4-5.

Hulka-Laskowski P., Zaratustra - twórca religii Iranu, Warszawa 1912.

Idem, Persja, Indie, Chiny [w:] Noty do wykladów pt. „Dzieje cywilizacji” wygłoszonych w stowarzyszeniu ,, Samoksztatcenie”, Żyrardów 1917-1919, Zbiory Specjalne Biblioteki Uniwersyteckiej w Łodzi, Rps 5037/3.

Idem, Droga do kultury. Szkic społeczno-religijny, Łódź 1922.

Idem, Bronisław Ferdynand Trentowski, „Jednota” 1926, nr 6, s. 94-95.

Idem, Krytyka grubiaństwem, „Jednota” 1926, nr 12, s. 183-184.

Idem, Porucznik Regier, Warszawa 1927.

Idem, Rekolekcje przedwyborcze, ,Jednota” 1927, nr 11, s. 161-163.

Idem, Do szeregów!, „Zwiastun Ewangeliczny” 1928, nr 2, s. 13-14.

Idem, Dokoła listu p. Simplexa. Przyznanie i wyznanie, „Zwiastun Ewangeliczny” 1928, nr 3, s. 19-20.

Idem, Demokracja i hierokracja, „Zwiastun Ewangeliczny” 1928, nr 4, s. 28-29.

Idem, Stare ceterum senso, „Zwiastun Ewangeliczny” 1928, nr 29, s. 221-222.

Idem, Świadomość i godność, „Zwiastun Ewangeliczny” 1928, nr 45, s. 430-431.

Idem, list do Jana Wantuły z 24.12.1928, Archiwum Jana Brody.

Idem, Co zostało skazane wyrokiem wileńskim, „Jednota” 1929, nr 1, s. 12-15.

\footnotetext{
${ }^{50}$ Idem, Pięć wieków..., s. 23.

${ }^{51}$ Ibidem.
} 
Idem, list do Jana Wantuły z 28.12.1929, Archiwum Jana Brody.

Idem, Polska wierzaca, Warszawa 1929.

Idem, Rola i zadania inteligencji ewangelickiej $w$ naszym życiu religijno-kościelnym. Referat odczytany na VI Zjeździe Polaków Ewangelików dnia 1 listopada 1929 r. w Krakowie, Warszawa 1930.

Idem, Pro Russia - contra Polonia, „Jednota” 1932, nr 11, s. 156-158.

Idem, Polska wspótczesna i ludzie tratwy, „Jednota” 1932, nr 12, s. 189-192.

Idem, Moim korespondentom, ,Jednota” 1933, nr 12, s. 174-175.

Idem, Spowiedź kalwina, „Wiadomości Literackie” 1933, nr 54, s. 1.

Idem, Mikołaj Rej, ,Jednota” 1934, nr 5, s. 71-73.

Idem, Człowiek, „Wiadomości Literackie” 1935, nr 27, s. 1.

Idem, Wileński Kościót Ewangelicko-Reformowany (b. Jednota litewska) na tle Reformacji i kultury polskiej, Wilno 1936.

Idem, Droga do ojczyzny i zapory, „Zwiastun Ewangeliczny” 1938, nr 11, s. 122-123.

Idem, list do Jana Sławiczka z 14.01.1942, Archiwum Jana Brody.

Idem, list do Pawła Kotasa z 16.12.1943, Archiwum Jana Brody.

Idem, Mój Żyrardów. Z dziejów polskiego miasta i z życia pisarza, Warszawa 1958.

Idem, Przedmowa [w:] idem, Pięć wieków herezji. Wypisy z literatury polskiej, Warszawa 1960, s. $18-51$

Leszczyński R. (senior), Paweł Hulka-Laskowski wobec kultury czeskiej [w:] Pawet Hulka-Laskowski (1881-1946). Szkice do portretu, R. Leszczyński (red.), Żyrardów 1995, s. 43-54.

Idem, Trudne życie [w:] Pawet Hulka-Laskowski (1881-1946). Szkice do portretu, R. Leszczyński (red.), Żyrardów 1995, s. 5-12.

Leszczyński R.M. (junior), Całożyciowe uczenie się Pawła Hulki-Laskowskiego (1881-1946) - stymulatory i bariery [w:] Biografia i badanie biografii, t. 4: Biografie i uczenie się, E. Dubas, J. Stelmaszczyk (red.), Łódź 2015, s. 67-83.

Lutostański K., Prawo cywilne obowiazujące w bytym Królestwie Polskim, t. 1, Warszawa 1931.

Pietrzak M., Prawo wyznaniowe, Warszawa 2003.

Rosica F. [Hulka-Laskowski P.], Polsko twa zguba w Rzymie, Chicago b. r.

W sprawie projektu ustawy o matżeństwie. Orędzie Episkopatu Polski, „Miesięcznik Kościelny Archidiecezji Gnieźnieńskiej i Poznańskiej” 1931, nr 11, s. 206-208. 